.. Üner, Köse, Yürümez, Ümit Yalçın, Akgül: Wood Waste Turned Into Value Added Products...

Birol Üner ${ }^{1}$, Gökhan Köse ${ }^{1}$, Yeşim Yürümez ${ }^{1}$, Ömer Ümit Yalçın², Mehmet Akgül

\title{
Wood Waste Turned Into Value Added Products: Thermal Plasticization by Benzylation Process
}

\section{Pretvorba drvnog otpada u proizvod dodane vrijednosti: toplinsko plastificiranje primjenom procesa benzilacije}

\author{
Original scientific paper • Izvorni znanstveni rad \\ Received-prispjelo: 16. 9. 2015. \\ Accepted-prihvaćeno: 6. 9. 2016. \\ UDK: $630 * 839.8 ; 630 * 812.14 ; 630 * 871.1$ \\ doi:10.5552/drind.2016.1534
}

\begin{abstract}
Sawdust is usually considered as waste in wood-using industries. These materials can be converted into value added thermoplastics by means of benzylation. Products can be utilized in different applications where plastics are used. Thermoplasticization process was carried out with benzyl chloride under different alkaline conditions, 15, 25 and $35 \%$, respectively. Alkali ions and concentration affect the substitution reaction. Tailored material structure was remarkably changed. In order to detect changes, crystallinity index of the materials and thermal properties were analyzed. In FTIR spectra, the peaks appeared at $698 \mathrm{~cm}^{-1}$ and $740 \mathrm{~cm}^{-1}$, which indicates the aromatic C-C angular deformation. Multiple peak appears at $3030 \mathrm{~cm}^{-1}$, which indicates benzylation of the materials. The peak increase can be observed at $1596 \mathrm{~cm}^{-1}$ due to the aromatic deformation. Benzyl groups attached to hydroxyl to form ether groups increase the peak intensity. As a result of that, hydrogen bond energy changes and crystallinity of the materials is reduced. This substitution of functional groups changes the decomposition temperature of modified materials. It reduces the decomposition temperature to between 330 and $350{ }^{\circ} \mathrm{C}$. Thermogravimetric analysis revealed that modified products were characterized by poorer thermal stability compared to raw materials.
\end{abstract}

Keywords: thermoplastic resin, hydrogen bond energy, crystallinity, thermal properties

SAŽETAK • Piljevina se u drvoprerađivačkoj industriji često smatra otpadom. Međutim, ona se postupkom benzilacije može pretvoriti u termoplastični materijal kao proizvod dodane vrijednosti. Tako dobiveni materijal moguće je upotrijebiti za različite namjene za koje se obično rabe plastične mase. Toplinski postupak plastificiranja provodi se benzil kloridom pri različitim lužnatim uvjetima $(15,25$ ili $35 \%$ ). Koncentracija lužnatih iona utječe na reakciju supstitucije. Struktura materijala značajno se mijenja. Radi otkrivanja promjene, analizirani su indeks kristaliničnosti materijala i toplinska svojstva. U infracrvenom dijelu spektra pikovi su se pojavili na $698 \mathrm{~cm}^{-1}$

\footnotetext{
${ }^{1}$ Authors are associate professor, undergraduate student and PhD student at Suleyman Demirel University, Faculty of Forestry Department of Forest Products Engineering, Isparta, Turkey. ${ }^{2}$ Author is professor at Suleyman Demirel University, Graduate School of Natural and Applied Sciences, Isparta, Turkey. ${ }^{3}$ Author is professor at Necmettin Erbakan University, Engineering Faculty, Material Engineering Department., Seydişehir/Konya, Turkey.

Autori su izvanredni profesor, dodiplomski student i doktorand Sveučilišta Suleyman Demirel, Šumarski fakultet, Zavod za inženjerstvo proizvoda baziranih na šumi, Isparta, Turska. ${ }^{2}$ Autor je profesor Sveučilišta Suleyman Demirel, Doktorska škola prirodnih i primijenjenih znanosti, Isparta, Turska. ${ }^{3}$ Autor je profesor Sveučilišta Necmettin Erbakan, Fakultet inženjerstva, Zavod za inženjerstvo materijala, Seydişehir/Konya, Turska.
} 
i $740 \mathrm{~cm}^{-1}$, što upućuje na aromatske C-C kutne deformacije. Višestruki maksimum pojavljuje se pri $3030 \mathrm{~cm}^{-1}$, što označava benzilaciju materijala. Zbog aromatske deformacije porast pika može se primijetiti na $1596 \mathrm{~cm}^{-1}$. Benzilne skupine vezane na hidroksilne skupine tvore eterske skupine i povećavaju intenzitet pika, zbog čega se mijenja energija vodikove veze $i$ kristaliničnost materijala se smanjuje. Taj postupak supstitucije na funkcionalnim skupinama mijenja temperaturu razgradnje modificiranih materijala. Smanjuje se temperatura dekompozicije na 330 i $350^{\circ} \mathrm{C}$. Termogravimetrijska analiza pokazala je da modificirani proizvodi imaju lošiju toplinsku stabilnost nego sirovina od koje su proizvedeni.

Ključne riječi: termoplastične smole, energija vodikove veze, kristaliničnost, toplinska svojstva

\section{INTRODUCTION}

\section{UVOD}

Increased utilization of wood results in more waste due to debarking, cutting, shaving, sanding, etc. How to deal with this waste is an important issue. Environmental concern and deficiency in natural resources impose solutions that involve reducing waste and recovering and recycling this material to conserve natural resources. Progress has been made in efforts to reduce waste, but additional works need to be done to solve this problem.

Sawdust and wood shavings are produced by a number of sectors and this raw material is part of the municipal waste stream. A tremendous range of products can be obtained from these lignocellulosic waste materials due to complexity of cell wall structure. Lignocellulosic materials refer to woody and nonwoody plants that are composed of cellulose, hemicellulose, and lignin. Chemical properties of these materials make them suitable for a large number of products. The utilization of lignocellulosic materials in the production of plastic and composites is becoming more and more attractive (Biswas et al., 2006; Bodirlau et al., 2008; Çöpür et al., 2007; Ebringerova and Heinze, 2000; Hassan et al., 2001; Hon and Luis, 1989; Hon and Ou, 1989; Pereira et al., 1997; Rowell, 1990; Su et al., 2015).

Plastics are being favored for many applications in place of other materials due to formability, light weight and strength properties (Hon and Shiraishi, 2001). In order to plasticize, lignocelullosic materials are chemically modified. Chemical modification of cell wall polymers is usually carried out either in acidic or alkali conditions (Chen et al., 2012; Huang et al., 2014; $\mathrm{Qu}$ et al., 2014). Chemical alteration of hydroxyl groups can reduce the interaction among the chain segments, creates free volume and changes the thermal properties of the material (Nakano, 1994). New modified lignocellulosic materials have thermoplasticity, when large or many side-chains are introduced by chemical modification.

Thermoplastic materials are usually produced from petrochemicals, which is dependent on limited source of fossil fuels whose price is fluctuating and may be running out. In addition to that, fossil fuels release gases which cause the greenhouse effect. One solution is to use tailored renewable resources. Therefore, the objectives of this paper were to explore the chemical modification of Turkish red pine sawdust via etherification to impart thermoplasticity. Thermo- plasticity was achieved by benzylation process, and characterization of the material was accomplished with crystallinity index and thermogravimetric analysis.

\section{MATERIAL AND METHODS 2. MATERIJALI I METODE}

\subsection{Materials}

2.1. Materijali

Turkish red pine (TRP) sawdust were obtained from the Isparta region in Turkey. Materials were dried under room temperature. Meal samples were prepared using a Wiley mill and ground to pass various mesh screens (60-80 mesh).

\subsection{Methods}

2.2. Metode

\subsubsection{Alkali treatment}

\subsubsection{Lužnata obrada}

Sawdust was treated with different concentrations of sodium, lithium, potassium hydroxide and guanidine for $24 \mathrm{hrs}$ at room temperature. After treatment, materials were rinsed and dried at $102 \pm 3{ }^{\circ} \mathrm{C}$ and tested with Fourier transform infrared spectroscopy (FTIR).

\subsubsection{Benzylation process}

\subsubsection{Proces benzilacije}

Benzylation process was used similarly to Hon and Ou process. Dried and ground samples (3 grams) were pretreated with various alkali concentrations $(15$, $25,35 \%$ ) for preswelling. The slurry was transferred to a $250 \mathrm{ml}$ round bottom flask containing benzyl chloride $(\mathrm{BC})(27.6 \mathrm{ml})$. The reaction was conducted at 110 ${ }^{\circ} \mathrm{C}$ for 6 hours with continuous stirring. The crude benzylated material was collected by filtration and exhaustively washed with water to remove any residuals and finally washed with ethanol to remove any residual benzyl alcohol. The final product was dried overnight at $40^{\circ} \mathrm{C}$.

\subsubsection{Fourier transform infrared spectroscopy} (FTIR)

\subsubsection{Fourierova transformacija infracrvene} spektroskopije

FTIR spectra were obtained on untreated and benzylated substrates from $\mathrm{KBr}$ pellet using Perkin Elmer spectrum one model FTIR spectrometer. Each sample was scanned 10 times between 4000 and 400 $\mathrm{cm}^{-1}$ and changes in the chemical structure were recorded. 
.. Üner, Köse, Yürümez, Ümit Yalçın, Akgül: Wood Waste Turned Into Value Added Products...

\subsubsection{Thermal properties}

\subsubsection{Toplinska svojstva}

Perkin Elmer Diamond model thermogravimetric analyzer (TGA) was used to study the thermal properties of etherified samples. The heating rate was set at $10{ }^{\circ} \mathrm{C} / \mathrm{min}$ and the temperature ranged from 25 to 600 ${ }^{\circ} \mathrm{C}$. Measurements on $4 \mathrm{mg}$ samples were carried out under nitrogen atmosphere $(100 \mathrm{ml} / \mathrm{min})$.

\section{RESULTS AND DISCUSSION}

\section{REZULTATI I RASPRAVA}

The degree of crystallinity is an important parameter for plasticization of lignocellulosic materials. Cell wall polymers contain significant amounts of hydroxyl groups. Chemical modification of lignocellulosic materials usually takes place between these hydroxyl groups of the cell wall polymers and chemical reagent with or without catalyst (Rowell, 1990). Tailored hydroxyl groups can help lignocellulosic materials to exhibit thermoplastic properties due to change in hydrogen bonding ability.

Introducing new chemicals to cell wall polymers causes breaking up of some hydrogen bonds and changes crystallinity. This change indicates the possibility of plasticization and can be detected with FTIR spectroscopy. In order to detect the change in crystallinity, different peak ratios and hydrogen bond energy can be used (Poletto et al., 2013; Akgul et al., 2007). The ratio between the heights of the bands at $1370 \mathrm{~cm}^{-1}$ and $2900 \mathrm{~cm}^{-1}$ was used to determine the total crystalline index (TCI), and the ratio between the areas of the bands at $1430 \mathrm{~cm}^{-1}$ and $896 \mathrm{~cm}^{-1}$ was used to determine lateral order index (LOI) of the materials (Akerholm, et al., 2004; Ma, 2007). The energy of the hydrogen bonds $E H$ for the $\mathrm{OH}$ stretching band was calculated using equation 1 :

$$
E H=\frac{1}{K} \cdot\left[\frac{\left(v_{o}-v\right)}{v_{o}}\right]
$$

Where $v_{o}$ is the standard frequency corresponding to free $\mathrm{OH}$ groups $\left(3650 \mathrm{~cm}^{-1}\right), v$ is the frequency

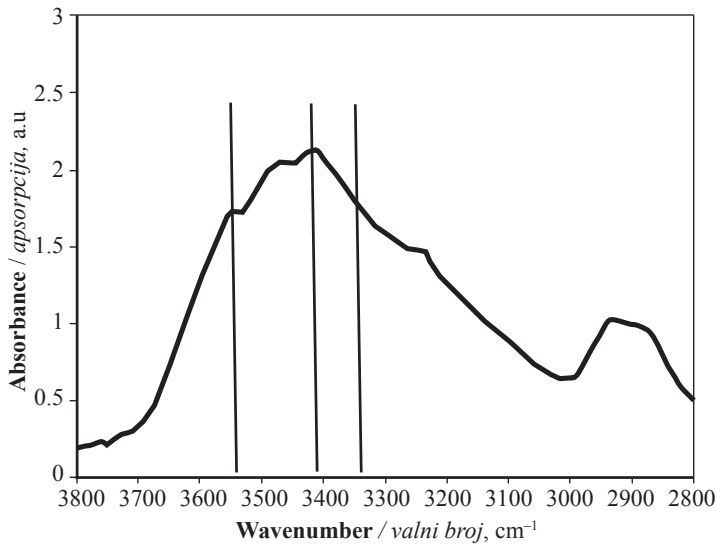

Figure 1 Assignment of hydroxyl bands in FTIR spectra for untreated Turkish red pine

Slika 1. Raspored hidroksilnih skupina na infracrvenom dijelu spektra za netretiranu piljevinu od drva turskoga crvenog bora

of the bonded $\mathrm{OH}$ groups, and $K$ is a constant $(1 / K=$ $\left.2.625 \cdot 10^{2} \mathrm{~kJ}\right)$.

In order to increase reactivity and swell lignocellulosic materials before modification, the material was treated with alkaline solution. Alkaline treatments contracts microfibrils in the cell wall and changes the dimension (Nakano, 2010). The mechanism of microfibril contraction and anisotropic dimensional changes of cells in wood are treated with aqueous $\mathrm{NaOH}$ solution. As a result, chemical reagent can reach and react with hydroxyl groups on cell wall polymers. In untreated materials, there are free, intra and inter hydrogen bonded hydroxyl groups available (Figure 1). The intramolecular hydrogen bond in lignin can be observed at 3560-3580 $\mathrm{cm}^{-1}$ (Kondo, 1997; Poletto et al., 2012). Intramolecular hydrogen bond in cellulose appears around $3430 \mathrm{~cm}^{-1}$ and $3340 \mathrm{~cm}^{-1}$ (Kondo, 1997; Poletto et al., 2014). After alkaline treatment, these hydroxyl groups affected crystalline structure changes. Table 1 shows the crystallinity and hydrogen bond energy change after alkaline treatment (Table 1).

There is a small difference in crystallinity index and hydrogen bond energy (EH) of the materials. TCI

Table 1 Crystallinity of alkaline treated materials of Turkish red pine (TRP)

Tablica 1. Kristaliničnost materijala piljevine turskog crvenog bora (TPR) tretiranog lužinama

\begin{tabular}{|l|c|c|c|c|c|c|}
\hline & \multicolumn{7}{|c|}{ Crystallinity of raw materials / Kristaliničnost sirovine } \\
\hline & TCI & LOI & EH $(\mathrm{kJ})$ & $\delta v\left(\mathrm{~cm}^{-1}\right) 2$ & $\delta v\left(\mathrm{~cm}^{-1}\right) 3$ & $\delta$ ( $\left.\mathrm{cm}^{-1}\right) 6$ \\
\hline Untreated Turkish red pine & 0.43 & 0.36 & 15.75 & 2.80 & 2.79 & 2.77 \\
\hline $15 \%$ NaOH TRP sawdust & 7.99 & 2.18 & 13.59 & 2.80 & 2.78 & 2.77 \\
\hline $25 \%$ NaOH TRP sawdust & 5.56 & 2.81 & 12.87 & 2.80 & 2.78 & 2.77 \\
\hline $35 \%$ NaOH TRP sawdust & 5.04 & 21.63 & 14.38 & 2.80 & 2.78 & 2.77 \\
\hline $15 \%$ KOH TRP sawdust & 1.50 & 9.43 & 16.54 & 2.80 & 2.78 & 2.77 \\
\hline $25 \%$ KOH TRP sawdust & 2.07 & 2.73 & 17.69 & 2.80 & 2.78 & 2.77 \\
\hline $35 \%$ KOH TRP sawdust & 2.24 & 10.74 & 17.04 & 2.80 & 2.78 & 2.77 \\
\hline $15 \%$ LiOH TRP sawdust & 3.61 & 1.17 & 16.54 & 2.80 & 2.78 & 2.77 \\
\hline $25 \%$ LiOH TRP sawdust & 1.96 & 1.37 & 17.98 & 2.80 & 2.78 & 2.77 \\
\hline $35 \%$ LiOH TRP sawdust & 2.14 & 1.44 & 20.35 & 2.80 & 2.78 & 2.77 \\
\hline $15 \%$ Guanidine TRP sawdust & 3.60 & 20.20 & 16.54 & 2.80 & 2.78 & 2.77 \\
\hline $25 \%$ Guanidine TRP sawdust & 4.70 & 0.25 & 17.40 & 2.80 & 2.78 & 2.77 \\
\hline $35 \%$ Guanidine TRP sawdust & 0.89 & 4.05 & 16.54 & 2.80 & 2.78 & 2.77 \\
\hline
\end{tabular}




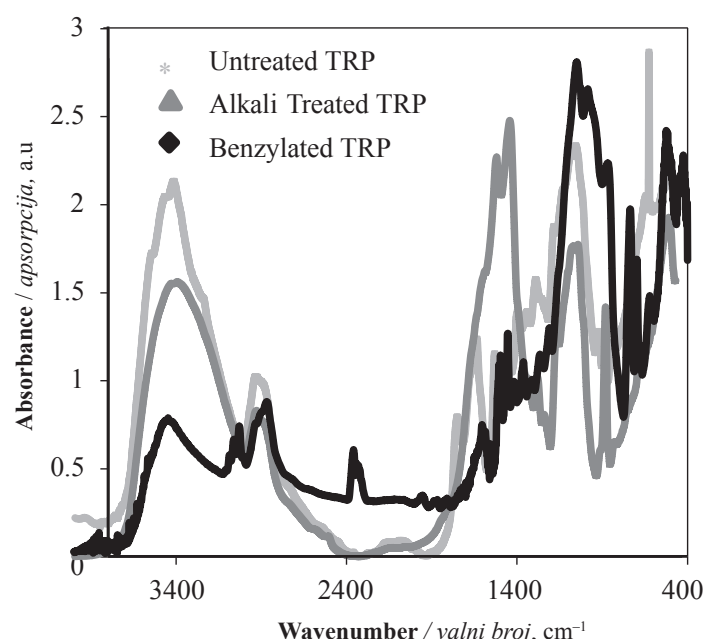

Figure 2 FTIR spectra of untreated and chemically treated TRP sawdust of Turkish red pine (TRP)

Slika 2. FTIR spektar netretirane i kemijski tretirane piljevine od drva turskoga crvenog bora

and LOI of the untreated sample were lower than those of alkaline treated materials. In contrast, hydrogen bond energy was high considering the alkaline treated materials. Alkaline treated samples change the crystalline structure and hydrogen bond energy and the degree of this change increases as $\mathrm{NaOH}<\mathrm{KOH} \leq$ Guanidine $<$ $\mathrm{LiOH}$ at the same concentration. Wood powder mercerization under alkaline conditions and the polymorphic
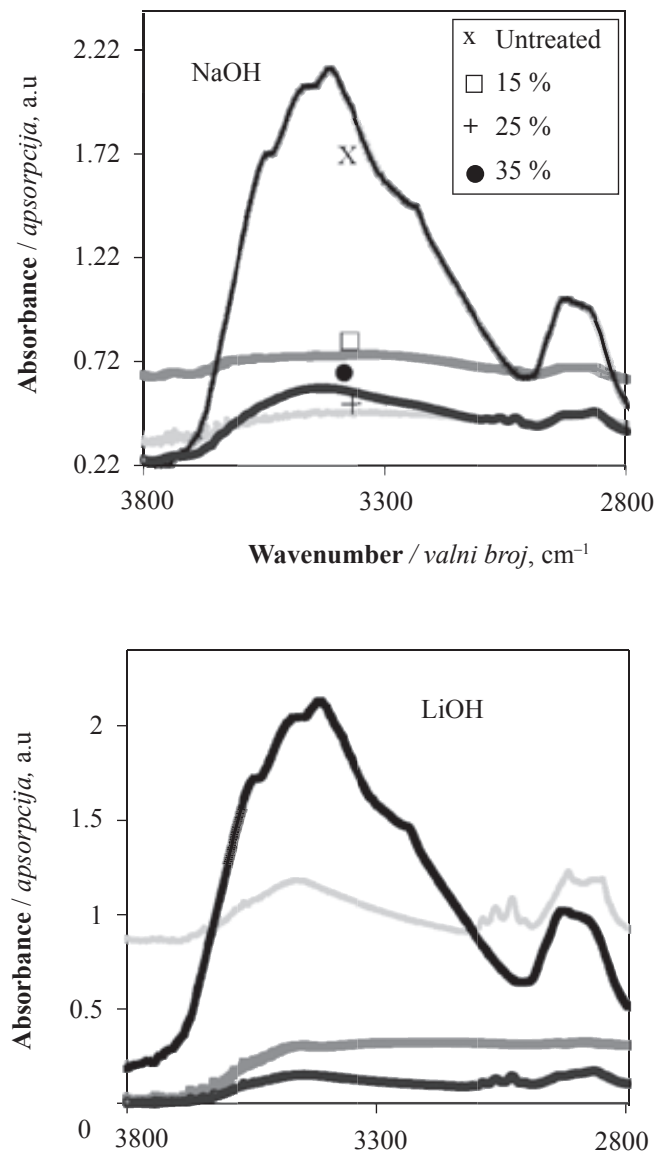

Wavenumber / valni broj, $\mathrm{cm}^{-1}$ transition take place under the alkaline solution. As the concentration of alkali, in particular $\mathrm{NaOH}$, increases, TCI decreases. In contrast to that, LOI increased with the $\mathrm{NaOH}, \mathrm{KOH}$ and $\mathrm{LiOH}$ concentration. It is probably due to the transition between cellulose polymorph and the effect of alkali ion (Nakano, 2010; Borysiak and Doczekalska, 2005). The lowest TCI and LOI values were observed on untreated materials, which may indicate that the amorphous region is higher in untreated materials than after alkali treatment when mercerization takes place. Hydrogen bond energy indicates the interaction between the adjacent cellulose chains (Poletto et al., 2012). It increases when cellulose chains approach each other, and the packing density also increases. There was a slight difference among bond distances in alkali treated materials. Hydrogen bond energy increased with alkali concentration.

After alkali treatment, the slurry was transferred to a round bottom flask containing benzyl chloride. The benzylation process proceeded with continuous stirring. Untreated and chemically treated samples show different FTIR spectra (Figure 2). Benzylation of the materials caused a reduction of hydroxyl peaks at $3400 \mathrm{~cm}^{-1}$ and an increase of the aromatic C-C axial deformations around $1595 \mathrm{~cm}^{-1}$ (Figure 3). In addition to that, aromatic multiple peak appeared at 3030-3100 $\mathrm{cm}^{-1}$. This could be due to monosubstituted benzyl rings. Guanidine showed spectra similar to those of untreated materials.

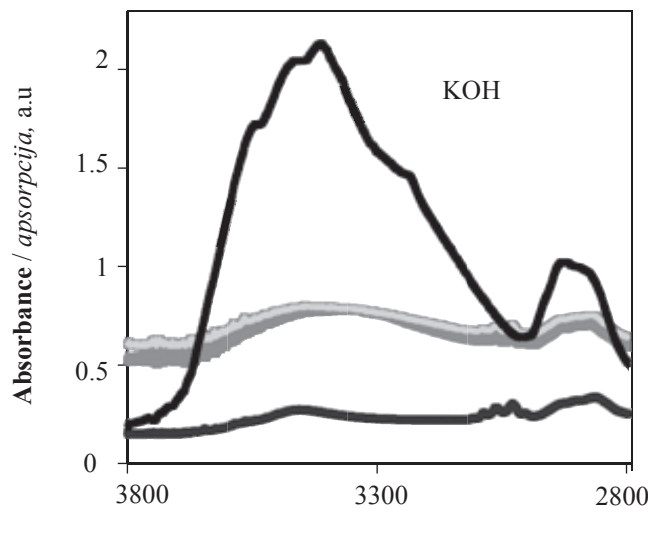

Wavenumber / valni broj, $\mathrm{cm}^{-1}$

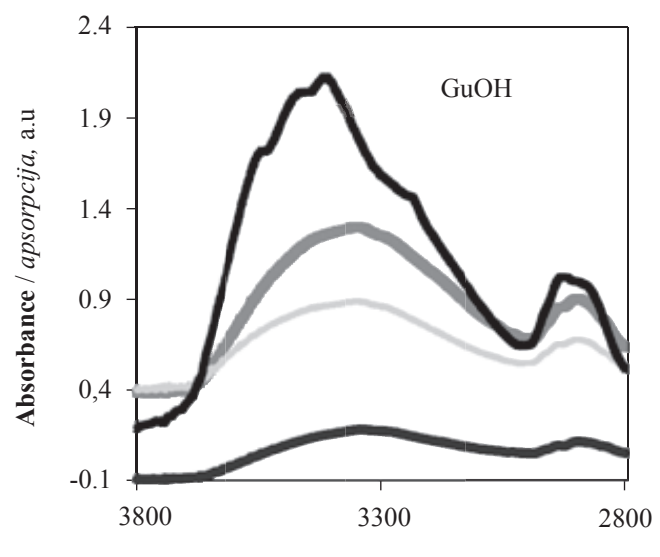

Wavenumber / valni broj, $\mathrm{cm}^{-1}$

Figure 3 Aromatic stretch at $3030-3050 \mathrm{~cm}^{-1}$ due to monosubstituted benzyl rings

Slika 3. Aromatski dio na $3030-3050 \mathrm{~cm}^{-1} \mathrm{zbog}$ monosupstitucije benzilskih prstenova 
.. Üner, Köse, Yürümez, Ümit Yalçın, Akgül: Wood Waste Turned Into Value Added Products...
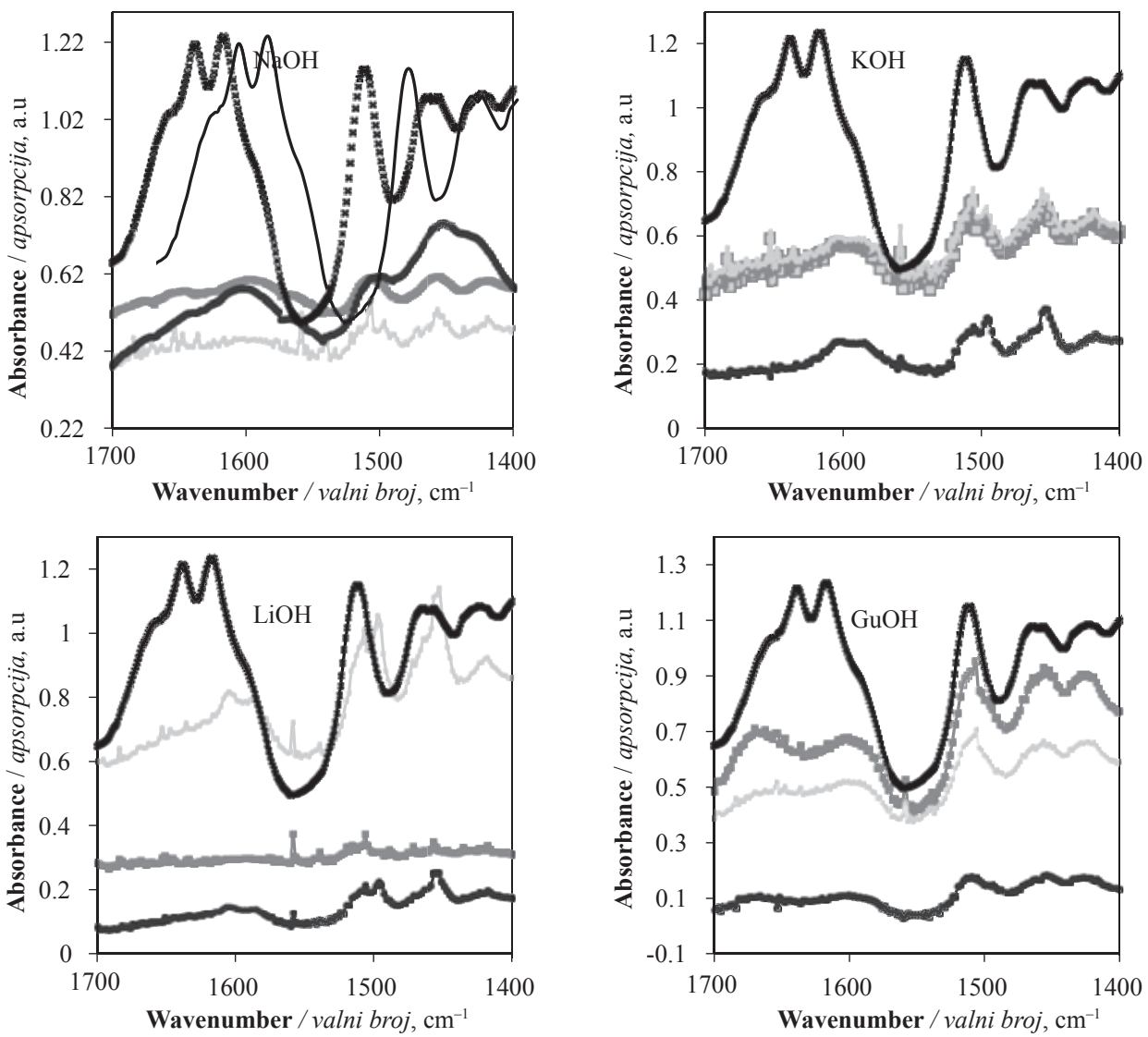

x Untreated $\square 15 \%+25 \%$ o $35 \%$

Figure 4 Increase of aromatic C-C axial deformations around $1595 \mathrm{~cm}^{-1}$ due to benyzlation

Slika 4. Porast aromatske C-C aksijalne deformacije oko $1595 \mathrm{~cm}^{-1}$ zbog benzilacije

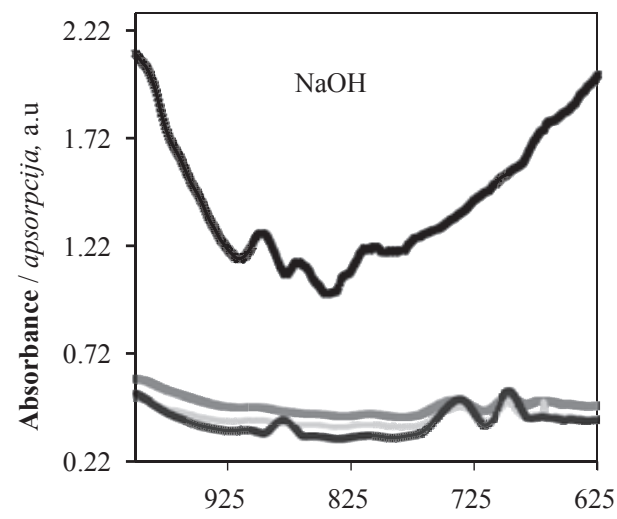

Wavenumber / valni broj, $\mathrm{cm}^{-1}$

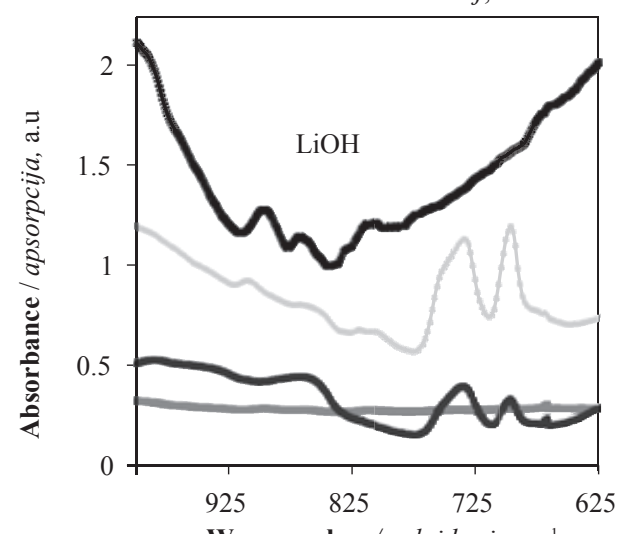

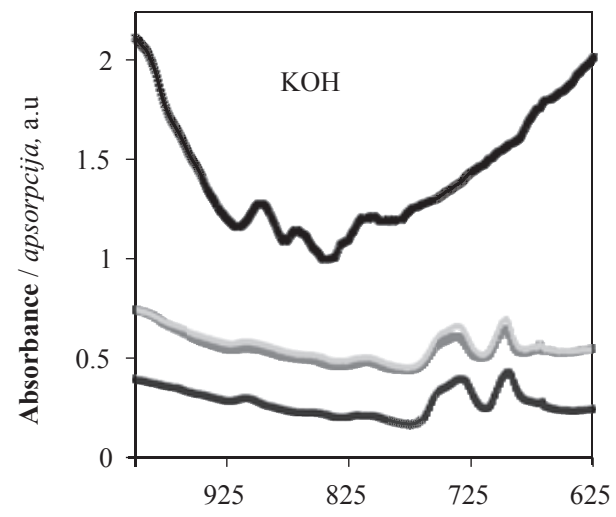

Wavenumber / valni broj, $\mathrm{cm}^{-1}$

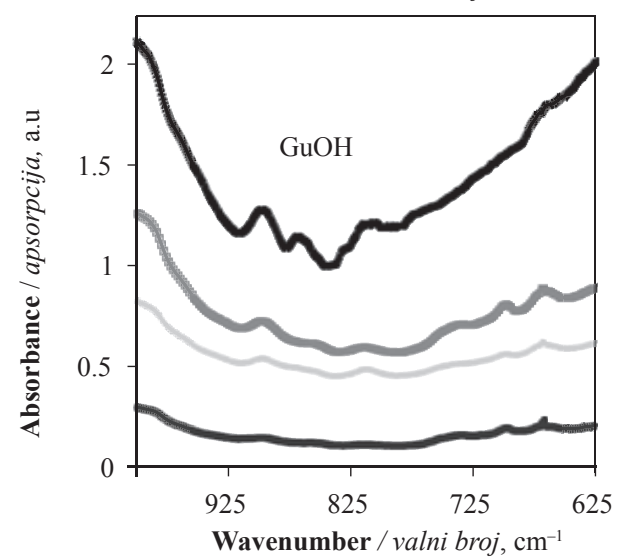

x Untreated $\square 15 \%+25 \%$ o $35 \%$

Figure 5 Appearance of bands at $698 \mathrm{~cm}^{-1}, 740 \mathrm{~cm}^{-1}$

Slika 5. Pojava skupina na $698 \mathrm{~cm}^{-1}, 740 \mathrm{~cm}^{-1}$ 

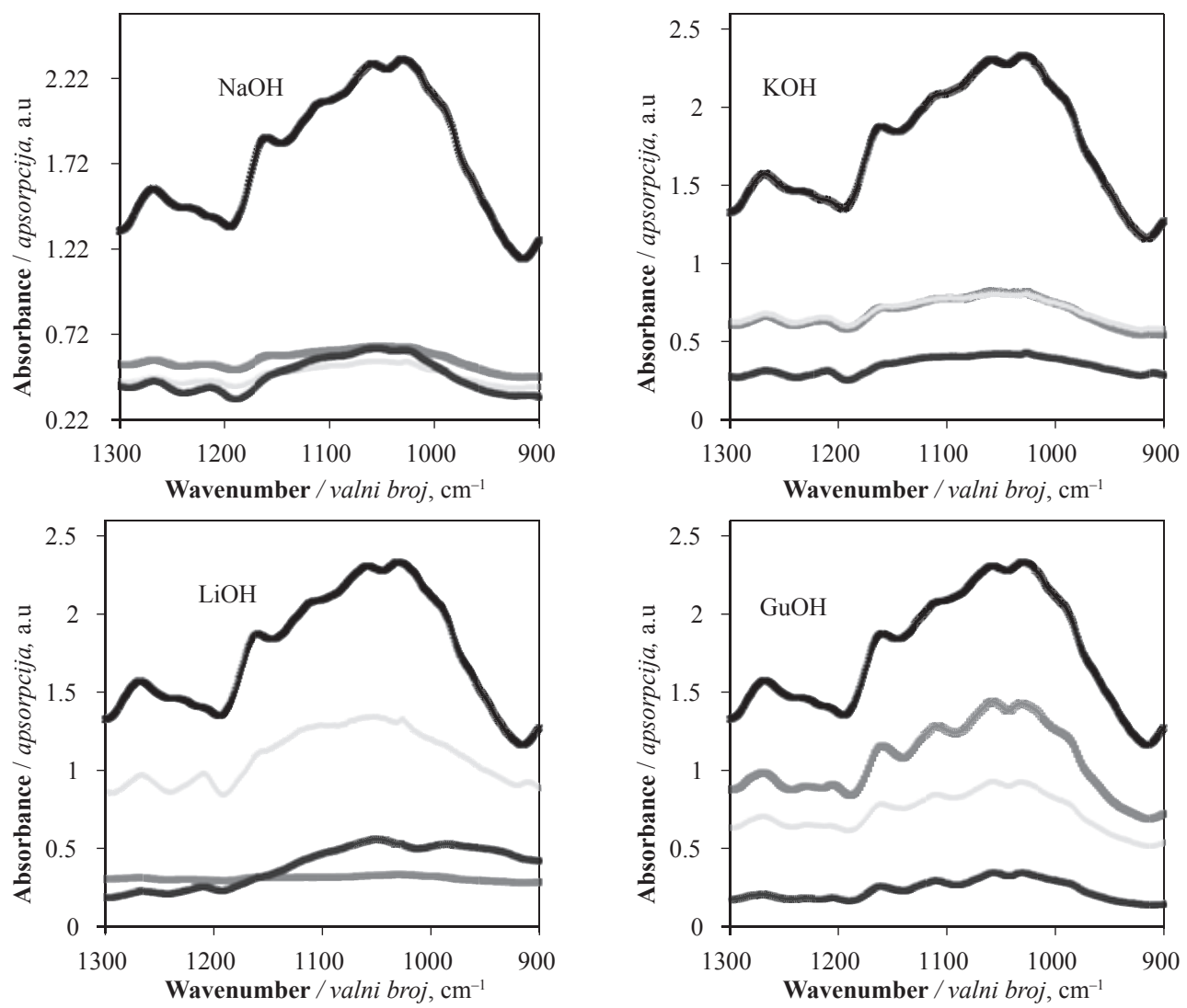

x Untreated $\square 15 \%+25 \%$ o $35 \%$

Figure $6 \mathrm{C}-\mathrm{O}$ stretch of the substituted benzyl ether

Slika 6. C-O dio etera koji je supstituiran benzilom

The peak at $670 \mathrm{~cm}^{-1}$ gives information on $\mathrm{C}-\mathrm{OH}$ out of plane bending (Ma, 2007). Spectra of the samples showed a reduction of peak intensity at $670 \mathrm{~cm}^{-1}$. In contrast, peak appears at $698 \mathrm{~cm}^{-1}$ due to aromatic $\mathrm{C}-\mathrm{C}$ angular deformation in treated materials (Figure 5). In addition to that, benzyl group can be detected at $740 \mathrm{~cm}^{-1}$. The guanidine peak is lower compared to others. Even though it is strong alkali, the size of the molecule may restrict the entrance into the cell wall. After the reaction, an increase of aryl ether band at $1265 \mathrm{~cm}^{-1}$ and of alkyl ether band at $1155-1060 \mathrm{~cm}^{-1}$ (due to C-O stretch from the substituted benzyl ether) was observed. (Figure 5). This absorbance band implied the substitution of hydroxyl groups in materials with benzyl groups.

Cellulose is the main component in wooden materials and it controls the thermal properties of wood (Hon and Shiraishi, 2001). Hydrogen bonds between cellulose chain and in the chain shift to melting temperature over decomposition temperature. Modification of wood helped to disrupt any hydrogen bonds between adjacent chains and in the chain. Therefore, it helps wood to become thermoformable.

Figure 7 shows differential thermogravimetric analysis (DTGA) curves of alkali treated with different alkali ions, concentration and untreated materials. The first step of weight loss, from room temperature to 120 ${ }^{\circ} \mathrm{C}$, was related to the evaporation of absorbed water. The second step ends near $410^{\circ} \mathrm{C}$, and can be described by an abrupt mass loss stage that was related to the main thermal decomposition process. A derivative weight loss curve can be used to tell the point at which weight loss is most apparent (Figure 8). According to the results obtained, raw materials begin to decompose at a higher temperature $\left(T_{\mathrm{i}}=380{ }^{\circ} \mathrm{C}\right)$ when compared to modified materials $\left(T_{\mathrm{i}}=330-340{ }^{\circ} \mathrm{C}\right)$.

It was seen that there was a significant difference between modified and untreated materials in relation to their respective thermal decomposition temperatures, which may be related to the difference in crystallinity between untreated and modified materials. Tailored hydroxyl groups change the crystalline structure of the materials, when the intra and intermolecular hydrogen bonds between chains are broken. Rearrangement of the bonding ability of the treated materials reduces the decomposition temperature. As a result, the crystalline domains in the untreated materials show a higher thermal stability, when compared to modified materials.

\section{CONCLUSION}

\section{ZAKLJUČAK}

Sawdust is a very promising source of raw materials for commercial products such as cellulose, plastics, etc. for many countries due to its availability and abundance. However, it is considered as waste. Thermoplasticization can be achieved by benzylation. Alkaline species and alkali concentration affect the substitution reaction and change the material properties. These changes are significant with $\mathrm{NaOH}$, and it can be detected with crystallinity, hydrogen bond energy change and thermal analysis. Hydroxyl groups were substituted 
.. Üner, Köse, Yürümez, Ümit Yalçın, Akgül: Wood Waste Turned Into Value Added Products...
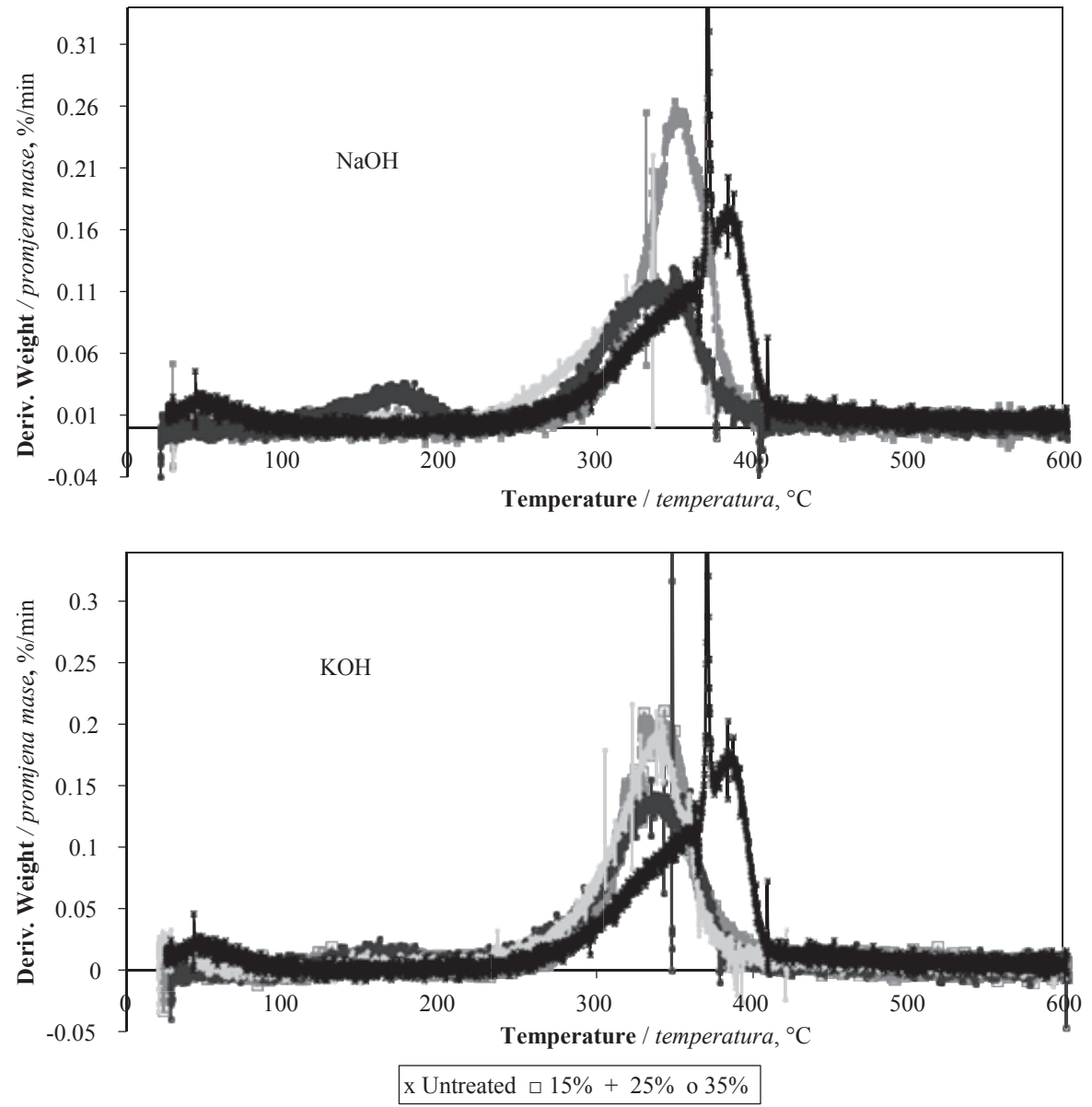

Figure 7 DTGA thermogram of untreated and benzylated wood with different alkali Slika 7. DTGA termogrami netretiranog drva i drva benziliranoga različitim lužinama
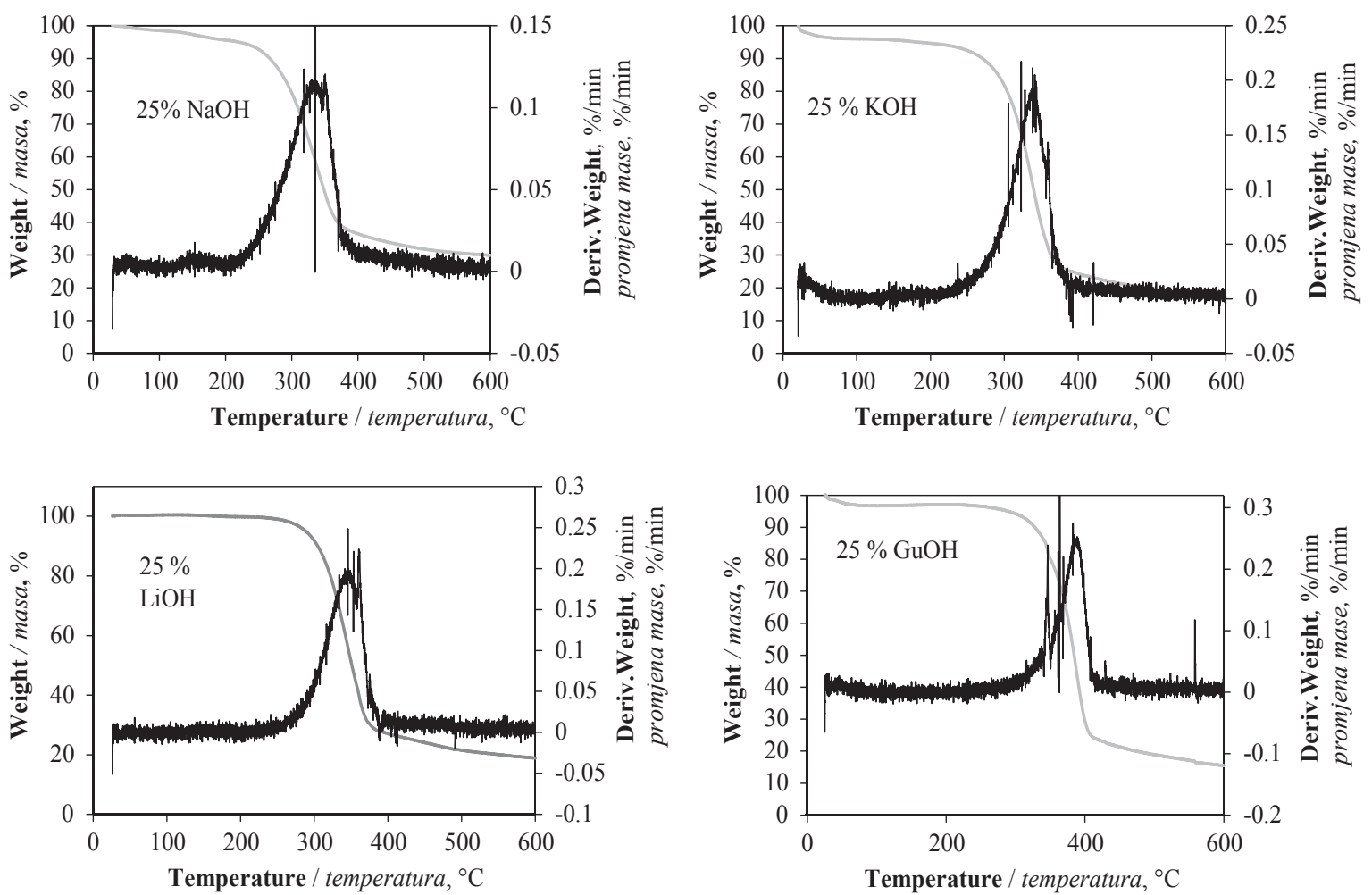

Figure 8 DTG thermograms of benzylated materials under different alkali concentrations

Slika 8. DTG termogrami benziliranog materijala pri različitim koncentracijama lužine 
with benzyl groups and this caused the change of FTIR spectra. Guanidine shows different trends. This could be due to the molecule size. It cannot penetrate the pore on the cell wall, because the pore size could be smaller than the molecule size. $\mathrm{Na} \mathrm{Li}$ and $\mathrm{K}$ are effective on thermoplasticization. Multiple peaks appear at around 3030 $\mathrm{cm}^{-1}$ indicating benzylation of the materials. The appearance of the peak at $698 \mathrm{~cm}^{-1}$ and $740 \mathrm{~cm}^{-1}$ indicates the aromatic C-C angular deformation. Thermogravimetric analysis revealed that modified products were characterized by poorer thermal stability compared to raw materials. Deformed crystallinity of the materials reduced significantly the decomposition temperature, and the reduction of the decomposition temperature ranged between 40 to $60{ }^{\circ} \mathrm{C}$.

\section{REFERENCES}

\section{LITERATURA}

1. Akgul, M; Gumuskaya, E.; Korkut, S., 2007: Crystalline structure of heat-treated Scots pine [Pinus sylvestris L.] and Uludag fir [Abies nordmanniana (Stev.) subsp. bornmuelleriana (Mattf.)] wood. Wood Science and Technology, 41: 281-289.

http://dx.doi.org/10.1007/s00226-006-0110-9.

2. Akerholm, M.; Hinterstoisser, B.; Salmen, L., 2004: Characterization of the crystalline structure of cellulose using static and dynamic FT-IR spectroscopy. Carbohydrate Research, 339: 569-578.

http://dx.doi.org/10.1016/j.carres.2003.11.012.

3. Biswas, A.; Saha, B. C.; Lawton, J. W.; Shogren, R. L.; Willet, J. L., 2006: Process for obtaining cellulose acetate from agricultural by-products. Carbohydrate Polymers, 64:134-137.

http://dx.doi.org/10.1016/j.carbpol.2005.11.002

4. Bodirlau, R.; Teaca, C. A.; Spiridon, I., 2008: Chemical Modification Of Beech Wood: Effect On Thermal Stability. Bioresources, 3 (3): 789-800.

5. Borysiak, S.; Doczekalska, B., 2005: X-ray Diffraction Study of Pine Wood Treated with $\mathrm{NaOH}$. Fibres \& Textiles in Eastern Europe January / December 2005, 13, No: 5 (53), 87-89.

6. Çöpür, Y.; Güler, C.; Akgül, M.; Taşçıŏlu, C., 2007: Some chemical properties of hazelnut husk and its suitability for particleboard production. Building and Environment, 42: 2568-2572.

http://dx.doi.org/10.1016/j.buildenv.2006.07.011.

7. Chen, C.; Cho, M.; Kim, B.-W.; Namb, J.-D.; Lee, Y., 2012: Thermo plasticization and characterization of kenaf fiber by benzylation. Journal of Industrial Engineering and Chemistry, 18: 1107-1111.

http://dx.doi.org/10.1016/j.jiec.2011.12.012.

8. Ebringerova, A.; Heinze, T., 2000: Xylan and xylan derivatives - biopolymers with valuable properties. Macromolecular Rapid Communication, 21: 542-556.

9. Hassan, M. L.; El-Wakil, N. A.; Sefain, M. Z., 2001: Thermoplasticization of Bagasse by Cyanoethylation. Journal of Applied Polymer Science, 79: 1965-1978.

10. Hon, D. N-S.; Louis, J. M. S., 1989: Thermoplasticization of Wood. II. Cyanoethylation. Journal of Polymer Science. Part A: Polymer Chemistry, 27: 4143-4160. http://dx.doi.org/.1002/pola.1989.080271221.

11. Hon, D. N.-S.; Ou, N.-H., 1989: Thermoplasticization of Wood. I. Benyzlation of wood. Journal of Polymer Science. Part A: Polymer Chemistry, 27: 2457-2482. http://dx.doi.org/10.1002/pola.1989.080270725.
12. Hon, D. N.-S.; Shiraishi, N., 2001: Wood and Cellulosic Chemistry, second edition. Marcel Dekker Inc. New York, Basel.

13. Huang, K.; Zhang, M.; Zhang, G.; Jiang, X.; Huang, D., 2014: Acetylation Modification of Rice Straw Fiber And Its Thermal Properties. Cellulose Chemistry and Technology, 48 (3-4): 199-207.

14. Kondo, T., 1997: The assignment of IR absorption bands due to free hydroxyl groups in cellulose. Cellulose, 4: 281-292. http://dx.doi.org/10.1023/A:1018448109214.

15. Ma, L., 2007: Plasticization of Wood By Benzylation. MSc. Thesis University of Idaho.

16. Nakano, T., 1994: Mechanism Of Thermoplasticity for Chemically-Modified Wood. Holzforschung-International Journal of the Biology, Chemistry, Physics and Technology of Wood, 48 (4): 318-324. http://dx.doi.org/10.1515/hfsg.1994.48.4.318.

17. Nakano, T., 2010: Mechanism of microfibril contraction and anisotropic dimensional changes for cells in wood treated with aqueous $\mathrm{NaOH}$ solution. Cellulose, 17: 711719. http://dx.doi.org/10.1007/s10570-010-9414-x.

18. Pereira, R.; Campana Filho, S. P.; Curvelo, A. A. S., 1997: Benzylated Pulps From Sugar Cane Bagasse. Cellulose, 4: 21-31. http://dx.doi.org/10.1023/A:1018459016966.

19. Poletto, M.; Pistor, V.; Zanetta, A. J., 2013: Structural Characteristics and Thermal Properties of Native Cellulose, in Cellulose, Fundamental Aspects Edited by Theo Van de Ven and Louis Godbout published by In Tech Croatia, 2013.

20. Poletto, M.; Junior, H. L. O.; Zattera, A. J., 2014: Native Cellulose: Structure Characterization and Thermal Properties. Materials, 7: 6105-6119. http://dx.doi.org/10.3390/ma7096105.

21. Poletto, M.; Zattera, A. J.; Santana, R. M. C., 2012: Strucural differences between wood species: Evidence from Chemical Composition, FTIR Spectroscopy and Thermogravimetric Analysis. Journal of Applied Polymer Science, 126, E336-E343. http://dx.doi.org/10.1002/app.36991.

22. Qu, B.; Qin, T.; Chu, F.; 2014: Cyanoethylation of several fiber materials and their utilization as adhesive in wood-based panels. Wood Science Technology, 48: 519531. http://dx.doi.org/10.1007/s00226-014-0623-6.

23. Rowell, R. M., 1990: Chemical Modification of Lignocellulosic Fibers To Produce High-Performance Composites. In: Glass, J. Edward; Swift, Graham (eds.). Agricultural and syntheticpolymers-Biodegradabilityandutilization. ACSsymposium series 433. American Chemical Society197th national meeting; 1989 April 9-14; Dallas, TX. Washington, DC: American Chemical Society; 1990. Chapter 21. https://doi.org/10.1021/bk-1990-0433.ch021.

24. Su, M.; Cheng, J.; Pan, Z.; Li, X.; Xu, A.; Hong, J., 2015: Study on the Preparation and Mechanical Properties of Injection-Moulded Wood-Based Plastics. Journal of Applied Polymer Science, 132 (5): 41376. http://dx.doi. org/10.1002/app.41376.

\section{Corresponding address:}

Assoc. prof. BIROL ÜNER, Ph.D.

Suleyman Demirel University, Faculty of Forestry

Department of Forest Products Engineering

Isparta 32260, TURKEY

e-mail: biroluner09@gmail.com 